Revista Água Viva

ISSN 1678-7471

\title{
FACES E IMPORTÂNCIA DA VIOLÊNCIA NO ROMANCE ASSIM NA TERRA COMO EMBAIXO DA TERRA, DE ANA PAULA MAIA
}

\section{FACES AND IMPORTANCE OF VIOLENCE IN THE NOVEL ASSIM NA TERRA COMO EMBAIXO DA TERRA, BY ANA PAULA MAIA}

Andre Rezende Benatti ${ }^{1}$

Mylena de Ávila Ferreira ${ }^{2}$

Recebido em: 20 jan. 2020

Aceito em: 13 jun. 2020

DOI 10.26512/aguaviva.v5i2.29257

RESUMO: O presente trabalho visa elucidar considerações sobre a violência, bem como salientar sua importância na obra Assim na terra como embaixo da terra (2017), de Ana Paula Maia, como mecanismo estético e estrutural do texto. A obra explora a violência por diferentes vertentes. Uma delas é o vínculo entre violência e poder. O enredo nos mostra a rotina de um presídio de segurança máxima totalmente isolado, cercado pela seca, vegetação escassa e solo áspero. Além do ambiente inóspito, os prisioneiros enviados a esse presídio se deparam com um diretor extremamente autoritário, violento e sádico, Melquíades, um homem perturbado que busca poder por meio de ações violentas, ameaças e pressão psicológica sobre seus ordenados e os detentos, ilustrando o conceito de violência subjetiva. Entre os detentos, um se destaca, Bronco Gil, um índio mestiço, com olho de vidro e assassino por encomenda, que fora condenado apenas por um crime, o assassinato de um prefeito. Bronco se torna o principal alvo de Melquíades, tanto por sua postura fria e indiferente ante à autoridade do diretor, quanto por seu histórico criminal. No decorrer da trama, episódios aterradores, como a caçada humana criada pelo diretor da colônia penal, nos evidenciam os reflexos da violência sobre a mente dos detentos. Melquíades expõe a perda da racionalidade e o aflorar da bestialidade em si, devido ao fascínio desenvolvido pela violência. No entanto, a brutalidade do diretor não é a única representação de violência presente na obra. Outras manifestações são abordadas por vieses que a superam, como os impactos na relação de poder e respeito entre agentes penitenciários e detentos. Para a compreensão do significado e significância da violência na obra de Ana Paula

\footnotetext{
1 Doutor em Letras Neolatinas: estudos literários neolatinos (literaturas hispânicas) pela Universidade Federal do Rio de Janeiro (2018); Mestre em Letras: estudos literários pela Universidade Federal de Mato Grosso do Sul (2013) e graduado em Letras, habilitação em Português/Espanhol, pela Universidade Estadual de Mato Grosso do Sul (2009). Atualmente é professor adjunto - nível IV da Universidade Estadual de Mato Grosso do Sul. Professor do quadro permanente do Programa de Pós-graduação (Mestrado) em Estudos de Linguagens da Universidade Federal de Mato Grosso do Sul. Professor permanente do Programa de Pós-graduação em Letras da Universidade Estadual de Mato Grosso do Sul. E-mail: andre benatti29@ hotmail.com

2 Graduada em Letras - Português/Inglês pela Universidade Estadual de Mato Grosso do Sul. E-mail: avilamylena98@gmail.com
} 
Maia, partir-se-á das contribuições teóricas e críticas de Hannah Arendt (2011) Slavoj Zizek (2014), Ronaldo Lima Lins (1990) e Xavier Crettiez (2011). Para além, na compreensão do texto literário de Maia, nos aportaremos em questões de ordem estrutural da narrativa.

PALAVRAS-CHAVE: Violência. Poder. Personagens. Assim na terra como embaixo da terra; Ana Paula Maia.

ABSTRACT: The present study aims to elucidate some considerations about violence, as well as to emphasize its importance in the book Assim na terra como embaixo da terra (2017), by Ana Paula Maia, as an aesthetic and structural mechanism of the text. The narrative explores violence by different strands. One of them is the link between violence and power. The plot brings us to the routine of a fully isolated maximum-security prison, surrounded by drought, scarce vegetation and rough soil. In addition to the inhospitable environment, the prisoners sent to this prison face an extremely authoritarian, violent and sadistic director, Melquiades, a disturbed man who seeks power through violent actions, threats and psychological pressure under his wards and detainees, illustrating the concept of subjective violence. Among the detainees, one stands out, Bronco Gil, a crossbred Indian with a glass eye and an assassin to order, who had been convicted only of the murder of a mayor. Bronco becomes the main target of Melquíades, as much for his cold and indifferent position before the authority of the director, as for its criminal record. Throughout the narrative, terrifying episodes such as the human hunt created by the director of the penal colony show us the reflexes of violence on the mind of detainees. Melquíades exposes the loss of rationality and the emergence of bestiality itself, due to the fascination developed by violence. However, the director's brutality is not the only representation of violence present in the novel. Other manifestations are approached by biases that overcome it, such as the impact on the relationship of power and respect between prison officers and prisoners. The understanding of the meaning and significance of violence in Ana Paula Maia's work will be based on the theoretical and critical contributions of Hannah Arendt (2011) Slavoj Zizek (2014), Ronaldo Lima Lins (1990) and Xavier Crettiez (2011). Moreover, in understanding the literary text of Maia, we will seek contribution in questions of the structural order of the narrative.

KEYWORDS: Violence. Power. Characters. Assim na terra como embaixo da terra. Ana Paula Maia.

\section{CONSIDERAÇÕES INICIAIS}

Abordar o termo Violência na literatura, perante suas distintas vertentes, não é algo simples. Segundo Zizek (2014), devemos inicialmente nos desprender da compreensão simplista do que conhecemos como violento. A violência se faz por diferentes meios e formas, ao analisá-la devemos nos distanciar para observar melhor o meio que a envolve, compreendendo assim a forma que se desenvolve, seus reflexos e sua importância na sociedade. 
A partir das definições do termo violência, partimos a pensá-la dentre as características da estética realista. Maia deixa evidente em sua escrita que a violência é o pano de fundo da sociedade, moldando o indivíduo ante a situação, podendo ser cômoda ou fazer-se necessária, contudo, permanecendo inevitável. Valendo-se dessa relação entre sociedade e violência, serão apontados trechos da obra de Maia para melhor elucidar a importância que os aspectos violentos possuem na construção do homem, seja ele parte do mundo empírico ou uma personagem representando o real.

Nascida no Rio de Janeiro, Ana Paula Maia é autora de sete romances, entre eles Carvão animal, De gado e homens e Assim na terra como embaixo da terra. Além de escritora Maia também é roteirista. Dentre seus trabalhos, destaca-se Deserto (2017), adaptação cinematográfica do romance Santa Maria do Circo, do escritor mexicano David Toscana. Atualmente contratada pela Rede Globo como roteirista da série Desalma, com lançamento previsto para 2020.

Sendo assim, nosso estudo tem como propósito pontuar aspectos da violência presentes na obra Assim na terra como embaixo da terra (2017), bem como identificar o papel da violência e da estética realista na escrita de Maia. Por ser contemporânea, poucos são os estudos sobre suas obras, no entanto, destacamos o trabalho Edgar Wilson: a personagem errante de Ana Paula Maia de Karina Kristiane Vicelli. ${ }^{3}$

Publicado em 2017, a obra Assim na terra como embaixo da terra nos apresenta uma Colônia Penal modelo, isolada em uma região árida e sem qualquer meio de comunicação com o exterior, regida por um diretor cruel, Melquíades, que viveu a maior parte da vida encarcerado assim como os apenados que guarda, perdendo assim qualquer resquício de humanidade e misericórdia. Somos apresentados também aos encarcerados. Destaca-se a personagem Bronco Gil, um índio mestiço que possui muita habilidade com a caça, além de trabalhar como assassino por encomenda, profissão que lhe garantiu uma vaga no cárcere. $\mathrm{O}$ enredo gira em torno da crueldade de Melquíades e da angústia de Bronco Gil; o primeiro se satisfaz realizando caçadas humanas na selva ao redor do presídio, já o segundo intenta escapar da prisão, e, consequentemente, da mira de Melquíades. Além de Melquíades e Bronco Gil, personagens

\footnotetext{
${ }^{3}$ Possui graduação em Letras pela Universidade Federal de Mato Grosso do Sul (1999), Mestrado em Estudos de Linguagens pela mesma instituição (2008), Doutorado em Letras também pela UFMS/CPTL (2014). Atualmente é Professora EBTT de Português no IFMS Campus Dourados. Tem experiência na área de Letras, atuando principalmente nos seguintes temas: Literatura Brasileira, Narrativas de Violência, Literatura Infantil, Produção Textual e Relação Inter-artes.
} 
como Taborda, o único carcereiro que permaneceu na colônia, e Valdênio, o detento mais antigo, são exemplos de diferente formas e reflexos da violência.

O presente estudo se divide em três tópicos, iniciando com a introdução do conceito de violência, seus aspectos, desdobramentos e suas representações na obra de Ana Paula Maia. No segundo tópico, introduzimos o conceito de Realismo e suas representações na literatura, com enfoque na literatura contemporânea brasileira. Por fim, desenvolvemos a análise da obra, destacando o papel da violência e sua importância dentro do enredo e, na sequência, apresentamos nossas considerações finais.

\section{SOBRE ASPECTOS DA VIOLÊNCIA E SEUS DESDOBRAMENTOS}

Do latim violentia, de violentus (com ímpeto, furioso, à força), entende-se o ato de força, a impetuosidade, o acometimento, a brutalidade, a veemência. Em regra, a violência resulta da ação ou da força irresistível, praticadas com a intenção de um objetivo, que não se teria sem ela. Juridicamente, a violência é espécie de coação, ou força de constrangimento, posto em prática para vencer a capacidade de resistência de outrem, ou para demovê-la, mesmo contra a sua vontade. É igualmente, um ato de força exercido contra as coisas na intenção de violentálas, devassá-las, ou delas se apossar. A violência, pois, é ação de violentar. E pode ser empregada na forma de violentação. Embora, em princípio, a violência ou violentação, importe num ato de força, num ato brutal, tomando, pois a forma física, tanto pode ser material, como pode ser moral, revelando-se nos mesmos aspectos em que se pode configurar a coação, ou o constrangimento. (DE PLÁCIDO e SILVA. Vocabulário Jurídico, 1996, Vol.III e IV. p.498499).

Superando as definições práticas, o termo violência dispõe de conceituações intrincadas que compreendem diversas camadas do relacionamento indivíduo/sociedade, como explica Slavoj Zizek em Violência: seis reflexões laterais.

Os sinais mais evidentes de violência que nos vêm à mente são atos de crime e terror, confrontos civis, confrontos internacionais. Mas devemos aprender a dar um passo para trás, a desembaraçar-nos do engodo fascinante desta violência "subjetiva" diretamente visível, exercida por um agente claramente identificável (ZIZEK, 2014, p. 17) 
A violência subjetiva compreende a violência derivada de uma interpretação individual ou coletiva do real, enquanto a violência objetiva (ou sistêmica) é uma violência quase imperceptível, pois, faz parte do que consideramos comum, se dá por processos sistêmicos, como a forma que governo e mídia manipulam grandes massas por meio do medo gerado pela violência subjetiva, como pontua Zizek: "Assim, a violência sistêmica é de certo modo algo como a célebre 'matéria escura' da física, a contrapartida de uma violência subjetiva (demasiado) visível.” (ZIZEK, 2014, p. 18) Por ser quase imperceptível, a violência objetiva é naturalmente introduzida na sociedade, um sistema que nos controla de modo sutil.

Como salienta Zizek (2014), a violência invisível se refere ao poder implicado na manipulação de grandes massas, é a busca pela prevenção da violência subjetiva que resulta na violência objetiva (invisível). Um exemplo desse poder é o controle camuflado, como a manipulação de líderes religiosos sobre seus seguidores. Zizek (2014) evidencia o papel do poder oculto utilizando o episódio de Mahatma Gandhi, que pregava a política de não-violência contra o domínio da Inglaterra sobre a Índia, mas que resultou na rebelião do povo, o qual aderiu à desobediência civil, ignorando as leis britânicas e até mesmo superando as divergências religiosas para se unirem em busca da independência do país, uma guerra pacífica que sucedeu a vitória da Índia sobre a Inglaterra.

Na literatura, utilizada muitas vezes como tema, a violência se torna responsável por reações como estranhamento ou desconforto, no entanto, sua importância vai além, seu retrato na literatura nos conduz à compreensão de aspectos significativos da obra, como a composição das personagens, sua ambientação e as relações com o poder.

A banalização da violência é consequência da naturalização de sua ocorrência, são vivências corriqueiras que resultam em menos impacto diante dessas situações. Um exemplo da banalização da violência é observado na obra Assim na terra como embaixo da terra, da escritora Ana Paula Maia, cujo enredo é repleto de aspectos cruéis, como os crimes cometidos pelos apenados, e o método de correção adotado pelo diretor do presídio, que concebe a caçada humana como medida punitiva. Tais aspectos presentes na obra são facilmente reconhecidos como parte do real empírico, a realidade da Colônia Penal da obra remete ao que acontece diariamente dentro dos presídios brasileiros.

Em decorrência de sua banalização, a violência é adotada como recurso estético na obra literária, tornando-se objeto para construção das relações de poder entre as personagens. Nessa 
construção destacam-se os papéis de opressor e oprimido, que demonstram de forma objetiva as características das diferentes formas de violência, o opressor enquanto detentor do poder, por meio de violência subjetiva ou objetiva, estabelece sua superioridade sobre o oprimido, subordinado impotente que se encontra em situação de inferioridade.

Na obra Assim na terra como embaixo da terra (2017), de Ana Paula Maia, a violência é responsável pela ambientação do enredo, além de ser abordada por dois vieses que se comunicam, seja ela objetiva ou subjetiva, além dos reflexos da violência sobre as personagens. Podemos destacar um exemplo do impacto da violência sobre as personagens ao analisarmos Melquíades, o diretor da penitenciária, que é responsável por manter a ordem e segurança no local, contudo, através da falta de contato com o exterior, acaba desenvolvendo uma personalidade cruel, que se satisfaz com a violência praticada contra os detentos. Já uma outra vertente da violência é observada na personagem Bronco Gil, que na adolescência é obrigado a passar pela transição de um jovem filho bastardo a capataz do pai e em seguida, assassino de aluguel. A violência de Bronco Gil é induzida aos poucos, o que é observado em trechos da obra como:

Desde que fora morar com o pai, um fazendeiro próspero e um tanto cretino, pegara gosto pelas caçadas de javali. Sua mãe tinha sido estuprada pelo pai. Bronco nascera na tribo onde fora criado até os doze anos, quando, por fim, o pai decidiu buscá-lo (MAIA, 2017, p. 45).

Durante outros trechos, observamos o desenvolvimento do caráter violento na personalidade de Bronco Gil, como: "Aprendeu mais do que poderia imaginar. Sua masculinidade se agravou ainda cedo. Mudou parte de seus hábitos. Deixou amenidades e meninices para trás" (MAIA, 2017, p. 46). No entanto, mesmo diante da transformação de sua índole, resquícios da humanidade ainda existentes em Bronco são expostos, no trecho "No caminho de volta para casa, precisou parar para vomitar. Matar um homem era muito diferente de matar javalis. Sentia-se fazendo o trabalho sujo dos outros, atando demônios alheios" (MAIA, 2017, p. 54). Ao vomitar, Bronco Gil esboça uma forma de violência, o ato do corpo expulsando o que lhe faz mal. Essa representação faz parte da expressão natural da violência, que constitui o homem.

Em sua obra As formas da violência (2011), Crettiez destaca o conceito elaborado pelo sociólogo francês Pierre Bourdieu (1992), a violência simbólica compreende a manifestação 
psicológica como ato violento, desprendendo-se da dimensão física. Ao pensar em violência, sua principal representação é assimilada ao dano físico, entretanto, a violência simbólica elucida o aspecto psicológico como ato violento. Um exemplo dessa violência é a relação da escola com o indivíduo. Os alunos são condicionados a seguirem condutas que são regidas pela figura dominante, professores e gestores escolares.

A violência não é facilmente percebida nessa situação, pois, os alunos apenas seguem as regras do ambiente escolar, sem notar que sua liberdade é violada a partir da privação de ir e vir dentro das salas, para ir ao banheiro necessita de permissão, para deixar a escola precisa esperar a liberação após o final do período letivo. Destaca-se que nesse caso da escola, ao praticar esse tipo de violência, o autor não tem conhecimento ou percepção do ato. Os alunos não seguem as condutas e critérios do meio escolar como forma de punição, é uma violência despercebida.

No entanto, em casos como crenças dominantes que impõem seus valores e comportamentos, o indivíduo que sofre a violência simbólica é inferiorizado, como se vê em exemplos de manifestações recorrentes são homofobia e racismo. No contexto social brasileiro, a presença da violência simbólica é evidenciada em comportamentos e/ou aspectos culturais corriqueiros como o racismo ou o machismo. O racismo se origina de estereótipos nacionais relacionados ao povo negro, retratando-o como uma raça inferior. A respeito do machismo, a violência simbólica é exposta pela dominação masculina sobre a mulher, que parte desde a desigualdade salarial até a inferiorização da mulher por ser considerada frágil.

\section{SOBRE O QUE PENSAMOS SER REALISMO, REAL E REALIDADE}

No dicionário Aurélio (1986, p. 1456), o termo real, do latim Reale, é compreendido como algo que existe de fato; verdadeiro; aquilo que é real. No mesmo dicionário, o conceito de REALIDADE é apresentado como: "Qualidade do que é real. ${ }^{2}$ Aquilo que existe efetivamente; real”. Enquanto o termo REALISMO é definido como: " 1 Qualidade ou estado do que é real. ${ }^{2}$ Atitude ou posição de quem se prende fielmente ao que é real, verdadeiro, às vezes de maneira prática, objetiva. ${ }^{3}$ Doutrina segundo a qual a arte deve expressar somente os caracteres essenciais da realidade".

Pesquisando os conceitos de real, realidade e realismo dados pelo dicionário, o leitor encontrará definições equivalentes, como se ambos fossem um só. Zizek aborda em sua obra a 
diferença entre realidade e real; segundo a visão lacaniana 'a 'realidade' é a realidade social dos indivíduos efetivos implicados em interações e nos processos produtivos, enquanto o Real é a inexorável e 'abstrata' lógica espectral do capital que determina o que se passa na realidade social" (Zizek, 2014, p. 24).

Jakobson (1970) ressalta que, para um teórico da arte o termo Realismo corresponde a uma corrente artística que busca reproduzir fielmente a realidade, prezando pela verossimilhança dentro da obra, ou seja, que segue a lógica do texto. Logo, são declaradas realistas as obras que nos parecem verossímeis.

Direcionando-se ao realismo contemporâneo brasileiro, destacam-se produções literárias como Cidade de Deus (1997), bem como sua adaptação cinematográfica homônima lançada em 2002, Estação Carandiru (1999) e cinematográficas como Tropa de elite (2007) e Carandiru (2003). Nessas produções, a realidade representada é muito próxima ao que acontece no cotidiano do cidadão brasileiro, logo, o adjetivo "realista" denota o sentido de fidelidade que é evidenciado por Jakobson (1970) no sentido generalizado do termo realidade. No entanto, Jakobson prossegue com sua definição de Realismo apontando suas ramificações, nos sãos apresentados as seguintes classificações:

1 - trata-se de uma aspiração, uma tendência, isto é, chama-se realista à obra cujo autor em causa propõe como verossímil (significação A). 2 - Chama-se realista a obra que é percebida por quem a julga como verossímil (significação B) (JAKOBSON, 1970, p. 120).

Nota-se que o sentido de Realismo varia entre o que o artista propõe como verossímil (significação A) e o que é percebido pelo leitor como verossímil (significação B), desse modo, na primeira situação somos direcionados a julgar de maneira inerente, quem concedeu o valor de realidade à obra foi o autor. Enquanto na segunda situação, a compreensão da verossimilhança é de critério individual.

$\mathrm{Na}$ literatura realista brasileira, a verossimilhança com a realidade é destacada em situações que acontecem de fato ou que aconteceriam, a identificação do público com o que é retratado é indubitável. Ao ler trechos da obra Estação Carandiru (1999) de Drauzio Varella, o leitor deparar-se-á com um episódio real, o presídio de fato existiu, a rebelião ocorreu e os mortos foram as provas do que restou do acontecido, mas além de retratar esse episódio isolado, 
o livro de Varella também representa a realidade das inúmeras penitenciárias brasileiras que vivem superlotadas, a mercê do descaso público e regidas pela violência.

No entanto, a verossimilhança não é considerada absoluta como característica do realismo, uma vez que o conceito de realismo também se deve ao afastamento dessa busca pela imitação, como aponta Barthes:

O realismo não pode ser [...] a cópia das coisas, mas o conhecimento da linguagem; a obra mais 'realista' não será a que 'pinta' a realidade, mas a que, servindo-se do mundo como conteúdo (este mesmo conteúdo é, aliás, alheio à sua estrutura, isto é, ao seu ser), explora o mais profundamente a realidade irreal da linguagem (BARTHES, 1964, p. 164).

Quando Barthes cita Flaubert, que descreve "um velho piano que suportava, sob um barômetro, um monte piramidal de caixas" (apud BARTHES, 2004, p. 181), a atenção da narrativa aos elementos citados serve para a ambientação do leitor, assim é notório que a presença do piano indica, de forma implícita, uma personagem de muitas posses. Logo, a construção da personagem se inicia antes de sua apresentação. Já a descrição do barômetro e as caixas amontoadas são parte da construção da projeção de realidade, pois são objetos irrelevantes para o enredo, mas que fazem parte da construção do espaço com características mínimas, que é o que ocorre na realidade empírica. Tal aspecto é o efeito do real projetado por Barthes.

Desviando a atenção do leitor para elementos "insignificantes”, Barthes opera o efeito do real, cada partícula do texto é responsável pela composição da realidade a ser apresentada a quem o lê. Contudo, Barthes (1964) critica o fazer mimético tradicional do realismo e a reprodução do real vivido ao dizer que o real não é representável, mas demonstrável.

Ao apresentar a concepção de realismo refratado, Tânia Pellegrini (2012) dialoga com Barthes (1964) a respeito do papel do realismo, que não deve ser cópia da realidade, mas o conhecimento da linguagem, que serve-se do mundo como seu conteúdo.

O realismo a que me refiro parece operar esteticamente, ao longo da história, uma refração da realidade e não uma 'cópia', uma 'imitação' ou mesmo 'interpretação', no sentido aristotélico, o que permite entender sua continuidade como corolário da persistência do mesmo 'mundo hostil' que the deu origem (PELLEGRINI, 2012, p. 12). 
Pellegrini (2012) afirma que o realismo continua vivo na literatura e presente nas formas narrativas contemporâneas. Tal declaração é evidenciada em obras como Olhos d'água (2014) de Conceição Evaristo, por exemplo; a obra é composta por quinze contos que narram o cotidiano de mulheres negras, evidenciando a violência urbana que sofrem, suas vidas são compostas por miséria, desigualdade social e preconceito.

Além do efeito do real e a fabricação da realidade, ao lidar com o termo realismo nos deparamos com outra nuance presente em seus conceitos, a crueldade. O realismo cruel é aquele que trata do caos urbano, violência e do grotesco, são realidades que, em teoria, são abominadas pela sociedade, visto que tratam de relatos sobre tragédias, perversões ou a maldade humana por ela mesma. Para melhor ilustrar a estética realista e seus aspectos cruéis, apresento o seguinte trecho da obra Cidade de Deus de Paulo Lins:

Lá em Cidade de Deus, um bicho-solto olhava aquele ser se mexendo com dificuldade em cima da cama. Levantou-se da cadeira cambaleando. Havia três dias que não se alimentava. Examinou as facas que tinha em casa, separou a maior, amolou-a na quina do tanque [...] Pensou em voltar atrás por um segundo, mas a determinação de fazer a mulher sofrer tinha bases sólidas, pois, desde o dia em que vira aquele ser nojento, um desejo de vingança se apoderara de seu íntimo, crescera amargamente, multiplicara-se à revelia e irreversivelmente se instalara ali dentro de seu peito. [...] Colocou o recémnascido em cima da mesa. Este, ainda no primeiro momento, agiu como se fosse ganhar colo. Segurou o bracinho direito com a mão esquerda e foi cortando o antebraço. O nenê revirava-se. Teve de colocar o joelho esquerdo sobre seu tronco. As lágrimas da criança saíam como se quisessem levar as retinas, num choro sobre-humano. [...] Juntou as partes do corpo como quem monta um quebra-cabeça, colocou tudo numa caixa de sapato, dirigiu-se para a casa da sogra sem dominar perfeitamente os passos. [...] O assassino tinha a sensação de estar vingado, faltavam poucos minutos para ver a mulher sofrendo como uma vaca no matadouro, porque era isso que ela era. Não aceitava que seu filho fosse branco, já que era negro e a desgraçada da mulher também [...] Antes de aproximar-se perguntou pela criança. O bicho-solto, em vez de responder, esperou que ela chegasse, destampou a caixa e disse: Entrega lá no pai do seu filho. Tava pensando que ia me enganar o tempo todo?! A mulher, num gesto impulsivo, puxou um dos braços da criança de dentro da caixa. Apenas um fio de sangue o ligava ao resto do corpo do bebê. A mulher desmaiou, o homem fugiu. Dias depois foi preso (2012, p. 51).

A partir do trecho extraído da obra de Paulo Lins (2012), aspectos cruéis que constituem a estética realista são destacados, como a violência e caos urbano, recorrentes na literatura 
contemporânea, tendo seu marco inicial entre o final do século XX e início do XXI. Diante da corrente literária que ressalta a brutalidade e crueldade presente na sociedade, questionamentos surgem a respeito de suas representações. É certo que o uso de temas como violência, sangue e mortes não são inéditos na literatura, no entanto a ascensão das narrativas brutais nos causam dúvidas a respeito de nossa moral.

Ao assistir o telejornal, o telespectador facilmente defrontar-se-á com notícias sobre episódios violentos do cotidiano, seja um assalto, acidente de trânsito ou homicídios. Tais episódios não nos causam espanto, são recorrentes, a sociedade se acostumou com a presença da violência em sua rotina. No entanto, ao se deparar com episódios como a descoberta de um serial killer ou um atentado, a curiosidade é instigada. Isso fica evidente ao se analisar o sucesso de programas sensacionalistas que promovem a dita "imprensa marrom”. Mesmo sem o apreço por serial killers, busca-se saber sobre seus crimes, suas motivações e sua vida. Essa fascinação pela brutalidade é parte do instinto humano. A problemática surge ao analisarmos a indiscriminação desse assunto diante das mídias, o uso da violência como meio estético ou simplesmente como sensacionalismo para gerar audiência foca no sucesso da disseminação do conteúdo e ignora o receptor. Um questionamento destacado por Renato Cordeiro Gomes no ensaio "Por um realismo cruel e brutal", presente no livro Novos Realismos (2012) nos leva a refletir:

Estariam os meios massivos pondo em imagens atos de crueldade até o limite do suportável? Poderíamos colocar no mesmo plano todo tipo de imagem agressiva, sem levar em conta a intenção, o contexto e o sentido da ação mostrada nas telas? (GOMES, 2012, p. 73).

A utilização da violência como artifício literário tem se tornado cada vez mais complexa devido a banalização que vem sofrendo, o tema violência passa a ser apenas mais um aspecto da vida contemporânea, logo, trabalhar com esse conceito requer muita habilidade e cuidado, para que a banalização não supere o impacto que a mesma deve ter sob o leitor. Nesse ponto, Ana Paula Maia adquire realce ao trabalhar com a violência de modo que o conceito não sobressai sobre seu enredo, o foco não é a violência, mas sua obra é construída a partir dela.

\section{SOBRE AS DIVERSAS VIOLÊNCIAS NO ROMANCE DE ANA PAULA MAIA}


Direcionando-nos ao título, Assim na terra como embaixo da terra, um sentimento de deja vu surge, a frase se assemelha ao trecho presente na oração do Pai Nosso, "Assim na terra como no céu”. Em sua obra, Maia não destaca a religião diretamente, mas utiliza partes dos aspectos que a constituem, como o inferno, ao se referir à Colônia e seus apenados, “[...] só restava cuidar dos demônios para que não fugissem do inferno" (2017, p. 71). Essa referência ao inferno se deve tanto ao clima dentro da Colônia, quanto às almas ali presas, sejam elas em cima da terra, os apenados, quanto embaixo da terra, aqueles que foram assassinados e permanecem presos, enterrados sob o terreno.

Analisando sua escrita, reconhecemos o realismo empírico representado por Maia. As condições da sociedade brasileira contemporânea, como o caos urbano, desigualdade social, violência e corrupção política, são aspectos que constituem suas obras. Esse método de escrita se assimila ao conceito de realismo proposto por Williams (2001), citado por Pellegrini: "uma forma particular de captar a relação entre os indivíduos e a sociedade" (2012, p. 13). As obras de Maia se constituem não somente da estética realista, mas também de suas ramificações como a brutalidade, a qual buscamos base em "Por um Realismo Cruel e Brutal", de Renato Cordeiro Gomes (2012) que nos coloca frente a frente com a realidade que incomoda, uma sociedade moldada pela violência e que também aparenta funcionar a seu favor, perpetuando um círculo vicioso.

No início da obra, Maia descreve a rotina e as características da Colônia Penal: poucos apenados e funcionários restaram, a vegetação é seca e escassa, o terreno da propriedade tem grande proporção, dentro de seus muros corre um estreito e fétido córrego, além da presença de uma pequena mata. Para Bachelard (2008, p. 25), "todo espaço realmente habitado traz a essência da noção de casa", o que podemos perceber completamente distante do que Ana Paula Maia cria em seu romance. Nada ali remete a qualquer conceito de casa, a espacialidade e ambientação do texto, nos mostra o contrário, ali não é o lugar do aconchego, ali é um local de punição, de purgação.

Citando Osman Lins, Antonio Dimas afirma que

Por ambientação, entenderíamos o conjunto de processos conhecidos ou possíveis, destinados a provocar, na narrativa a noção de determinado ambiente. Para aferição do espaço levamos a nossa experiência do mundo; para ajuizar sobre a ambientação, onde transparecem os recursos expressivos 
do autor, impõe-se um certo conhecimento da arte narrativa (LINS apud DIMAS, 1987, p. 20)

Deste modo, percebemos em Assim na terra como embaixo da terra (2017) espaço e ambientação como complementares, pois são eles que, de alguma forma, ditarão as regras pelas quais as outras microestruturas narrativas irão se construir. É o próprio ambiente que transforma a personagem de Melquíades em um louco sádico que caça outros seres humanos como se fossem animais selvagens, é o ambiente que inquieta todas as outras personagens, e é dali que os encarcerados querem fugir.

Os presos enviados para a Colônia são condenados por crimes hediondos, então já chegam desesperançosos devido à gravidade de suas condenações e às condições da prisão. No entanto, após anos de funcionamento a Colônia recebe a notícia de uma possível extinção.

Aguardam uma ordem, um comboio que virá buscá-los e levá-los a outra parte, mas a consternação aumenta desde que a comunicação com o lado de fora dos muros silenciou. As linhas telefônicas estão interrompidas há dias, e a última notícia que tiveram é que um oficial há de chegar ao local para uma inspeção final e os conduzirá ao destino seguinte. De acordo com os cálculos, o oficial está atrasado em pelo menos sete dias (MAIA, 2017, p. 9-10).

No trecho destacado, observa-se a angústia dos apenados ao esperar aquilo que pode ser sua última esperança. A vinda do oficial representa uma espécie de salvação, pois permanecerão presos, mas têm a oportunidade de serem realocados, escapando assim do sadismo de Melquíades e também do ambiente da Colônia Penal, que torna a vida das personagens insuportável.

A personagem de ficção é criada a partir de uma perspectiva humana e representa algo que se aproxima deste humano, é impossível que qualquer romancista escreva qualquer tipo de literatura sem ter como base a vida empírica. Segundo Forster, "A vida oculta é, por definição, oculta. A vida oculta se manifesta via sinais exteriores já deixou de ser oculta, e ingressou no domínio da ação. E a função do romancista é revelar a vida oculta em sua fonte, [...]" (FORSTER, 2004, p. 65), e é exatamente o que faz Ana Paula Maia. Por mais perversas e insensíveis que sejam as personagens que cria, por mais que detestemos as atitudes de Melquíades, ou de Bronco Gil ou de qualquer outra pessoa da narrativa de Maia, as pessoas 
criadas pela autora são completamente humanas, revelam faces humanas que, normalmente, são colocadas em segundo plano, marginalizadas.

Para Beth Brait,

Como um bruxo que vai dosando poções que se misturam num mágico caldeirão, o escritor recorre aos artifícios oferecidos por um código a fim de engendrar suas criaturas. Quer elas sejam tiradas de sua vivência real ou imaginária, dos sonhos, dos pesadelos ou das mesquinharias do cotidiano, a materialidade desses seres só pode ser atingida através de um jogo de linguagem que torne tangível a sua presença e sensíveis aos seus movimentos (BRAIT, 1993, p. 52).

Nas doses certas Maia criou o perfil cruel de Melquíades, a ponto de os leitores torcerem por detentos que cometeram crimes hediondos. Por exemplo, ao ler a seguinte atitude da personagem: "Melquíades dá um pulo da cadeira e bate palmas uma vez. Seu entusiasmo tem se tornado cada vez mais estranho, e a perturbação no seu modo de agir tem afligido a todos na Colônia" (MAIA, 2017, p. 12). O deterioramento da lucidez de Melquíades é observado a partir de episódios como o trecho exposto, além de expor também a visão das personagens que o rodeiam.

Relacionando a Literatura ao mundo empírico, perceber-se-á que as personagens torna-se mais "concretas", ou coerentes que as pessoas "reais", pois o limite de ação de cada personagem é delimitado por seu criador. No caso do romance em questão, os limites de Melquíades, como um homem que se tornou perturbado, talvez, por conta de seu ambiente de trabalho, os limites de ação são bem delimitados, ele não tem como fugir dali, não há para ele outras possibilidades do que seguir com sua vida da maneira como ela já ocorre. Segundo Rosenfeld, a personagem apresenta

[...] maior exemplaridade, maior significação; e paradoxalmente, também maior riqueza - não por serem mais ricas do que as pessoas reais, e sim em virtude da concentração, seleção, densidade e estilização do contexto imaginário, que reúne os fios dispersos e esfarrapados da realidade num padrão firme e consciente. Antes de tudo, porém, a ficção é o único lugar em termos epistemológicos - em que os seres humanos se tornam transparentes à nossa visão, por se tratar de seres puramente intencionais sem referência a seres autônomos; de seres totalmente projetados por orações. (Rosenfeld, 2002, p. 35). 
A situação do encarceramento afeta a todos, no entanto, uma personagem merece destaque: Valdênio, o encarcerado mais antigo da Colônia. Seu tempo de encarceramento o condicionou a um mundo obsoleto.

O mundo mudou, e ele também, mas não na mesma sintonia. Valdênio tornouse mais velho, doente e não muito mais esperto. O mundo recrudesceu. Ser jogado para fora dos muros seria para ele entrar num outro confinamento de sobrevivência e resistência que já não pode mais replicar (MAIA, 2017, p. 15).

O despertar da violência em Bronco Gil é evidenciado na passagem que aborda sua origem, filho bastardo nascido de um estupro, é levado para morar com o pai, onde aprende a caçar e posteriormente se torna assassino por encomenda.

Desde que fora morar com o pai, um fazendeiro próspero e um tanto cretino, pegara gosto pelas caçadas de javali. Sua mãe tinha sido estuprada pelo pai. Bronco nascera na tribo onde fora criado até os doze anos, quando, por fim, o pai decidiu busca-lo. Aprendeu mais do que poderia imaginar. Sua masculinidade se agravou ainda cedo. Mudou parte de seus hábitos. Deixou amenidades e meninices para trás (MAIA, 2017, p. 45-46).

No entanto, a Bronco Gil não deve ser atribuído o adjetivo de vítima, pois possui plena consciência de sua personalidade, como evidenciado no trecho: "Bronco Gil não é um homem bom e sabe disso, não espera ser tratado de acordo com seu caráter, mas de acordo com sua conduta dentro dos muros" (MAIA, 2017, p. 27).

Se para Candido, “[...] podemos variar relativamente a nossa interpretação da personagem; mas o autor lhe deu, desde logo, uma linha de coerência fixada para sempre, delimitando a curva de sua existência e a natureza do seu modo de ser” (CANDIDO, 2002, p. 59), podemos afirmar que as personagens de Assim na terra como embaixo da terra não tem como fugir da violência que os constitui enquanto seres humanos, pois foram concebidos de tal maneira. Eles não podem fugir de sua própria constituição como humanos, de sua composição, esta dada por Maia através de seu narrador.

Assim como acontece com Bronco Gil, em Melquíades a violência é despertada inicialmente por seu pai: “Aprendeu com o pai, um ex-policial, que o melhor lugar para se 
manter um bandido é embaixo da terra". (MAIA, 2017, p.80), no entanto, o que os difere é a forma como a violência se agrava quando Melquíades passa a trabalhar na Colônia.

Melquíades estava em início de carreira quando foi enviado à Colônia. Passou mais tempo atrás daqueles muros do que a maioria dos criminosos que disciplinou. Dedicou a vida a permanecer encarcerado, contendo a maldade atrás dos muros. Ali não havia homem bom; talvez algum deles já tivesse conhecido a bondade um dia, porém o tempo cuidou de apagar qualquer traço do que possa ter havido de bom neles. Melquíades já havia perdido toda a sua bondade, inocência e misericórdia; [...] (MAIA, 2017, p. 71).

Ao contrastar Melquíades e Bronco Gil observa-se que ambos são gerados pela violência e a partir dela se formam, mas um aspecto essencial difere entre os dois, o impacto da violência em cada personagem. Melquíades encontra na violência a satisfação, o prazer, enquanto Bronco descobre um modo vida, não faz porque sente prazer, mas porque é pago por isso. Os reflexos da violência na vida das personagens distinguem-se; contudo, existe uma semelhança evidente: a perpetuação do ato violento. A violência das obras de Ana Paula Maia, de maneira geral, representa grande parcela da contemporaneidade, apesar de sua diegese estar em outro tempo. A representação da realidade na obra de Ana Paula Maia dialoga com a conexão e desconexão simultânea da realidade apontada por Schollhammer:

[...] cria imagens literárias que são conectadas à realidade, mas também desconectadas, são simultaneamente reais e artificiais, afetivas e frias, críticas e complacentes. Para Hal Foster é essa possibilidade de coexistência simultânea dos dois modos de representação que constitui o que denomina o Realismo traumático, uma imagem marcada pelo limite do que pode ser representado e ao mesmo tempo índice e arquivo dessa mesma impossibilidade. Trata-se aqui de uma inversão significativa da ideia do Realismo tal como vinha sendo entendido até então, pois se o Realismo histórico era comprometido com a representação sustentada na verossimilhança e na objetividade científica, e se os "novos realismos" de Bertolt Brecht a Alejo Carpentier evocavam uma noção de real com certa demanda de realidade objetiva e confiança numa referência forte, o Realismo extremo evoca a derrota da representação. A referencialidade é identificada por Foster nos efeitos de um real impossível, em decorrência da derrota das possibilidades representativas (SCHØLLHAMMER, 2012, p. 135-136). 
A realidade construída a partir da violência é o ponto principal da obra, é muito próximo do empírico. Maia nos coloca frente a realidade cruel com a qual estamos familiarizados. Quando Maia afirma:

O confinamento de homens assemelha-se a um curral de animais. O gado é abatido para se transformar em alimentos; os homens, por sua vez, são abatidos para deixarem de existir. Não é um lugar de recuperação ou coisa que o valha, é um curral para se amontoarem os indesejados, muito semelhante aos espaços destinados às montanhas de lixo, que ninguém quer lembrar que existem, ver ou sentir seus odores (MAIA, 2017, p. 97).

Apesar de figurar dentre os romances que poderíamos julgar como absurdos, o tex to da escritora carioca é demasiadamente real e contemporâneo. No romance podemos perceber claramente questões que tocam a perversidade e a violência humana, tão presentes na contemporaneidade, todavia estas aparecem representadas em situações que ao mesmo tempo nos parecem absurdas. Melquíades, um homem daltônico, vai à caça de seus prisioneiros em noites de lua cheia.

Quando estabelecemos uma relação entre a violência e as manifestações culturais e artísticas, é para sugerir que a representação da violência manifesta uma tentativa viva na cultura brasileira de interpretar a realidade contemporânea e de se apropriar dela, artisticamente, de maneira mais "real", com o intuito de intervir nos processos culturais (SCHØLLHAMMER, 2013, p. 43).

Desta forma, percebe-se como a artista realiza uma criação que aproxima a Literatura da realidade, de maneira a fazer parte desta para poder representá-la. As interpretações que a romancista tem da realidade brasileira, por mais que se afastem propriamente de um espaço geográfico, ou que não tenham referências a qualquer lugar, região ou algo que identifique o território nacional, tem como referência extrema a violência que assola o país há décadas. Poderíamos cogitar dizer, de alguma forma, que a Literatura de Maia é grandiosamente Real. Fala de um Brasil real, de um Brasil que existe e que não se encontra em um ou outro canto territorial, mas em todo o território nacional, um Brasil sem perdão, violento e cruel. 


\section{CONSIDERAÇÕES FINAIS}

Através do presente estudo, podemos concluir que a obra Assim na terra como embaixo da terra de Ana Paula Maia detém diferentes aspectos e formas de violência, como a forma que a violência reflete na vida das personagens, quais sãos suas consequências e o modo como o homem se constitui pela violência. O foco de nosso estudo foi destacar a importância da violência na obra e revelar seu papel diante do realismo contemporâneo brasileiro. Vale ressaltar que Maia não utiliza a violência como tema, mas como meio estético e como molde para a construção das personagens. O ambiente no qual o enredo se desenvolve é violento e as personagens são originadas de vidas violentas, contudo, o destaque não é a ação violenta, mas seus reflexos, como o homem é consumido pela violência e ao mesmo tempo não consegue evitá-la.

As características da violência no enredo perpassam a esfera física e explícita, nos apresentando a forma como a sociedade é moldada e como os aspectos violentos se fazem necessários na construção do indivíduo. As personagens são formadas a partir da presença da violência em suas vidas, sofrem primeiramente com o reflexo de seus atos quando são condenadas e enviadas à Colônia Penal, em seguida, se deparam com o sistema prisional regido por um homem autoritário e sádico, que violenta os apenados e os funcionários do presídio através da relação de poder e submissão, ao final, a violência se torna insuperável, faz parte de cada personagem e continuará presente em suas vidas, seja de forma direta ou indireta.

A escrita de Maia e as características do Realismo Brutal de Gomes (2012) se assemelham diante da forma com que trabalham a violência. Na obra de Ana Paula Maia, a representação da violência urbana cabe mesmo no ambiente rural onde as personagens vivem, pois supera a oposição entre a vida do campo e da cidade, uma vez que se concebe a vida no meio rural como pacata e no meio urbano como violenta. No entanto, observamos dentro da obra o deslocamento da violência para o meio rural, demonstrando sua presença em todo lugar e de inúmeras formas.

Em suma, Maia constrói uma ligação entre ficção e o mundo empírico através dos aspectos do realismo que utiliza em suas obras. Suas histórias são violentas e predominantemente masculinas, as personagens são homens sujos, brutos e ignorantes que possuem vidas medíocres, a violência os rodeia e faz parte da sua construção. Mesmo que não trabalhe o espaço geográfico em suas obras, Maia representa a realidade que faz parte do 
cotidiano de qualquer brasileiro, sendo assim, os aspectos rurais, brutais e violentos resultam na indiscutível identificação com o real empírico que vivemos.

\section{REFERÊNCIAS}

ARENDT, Hannah. Sobre a violência. Tradução André de Macedo Duarte. - 3.ed. - Rio de Janeiro: Civilização Brasileira, 2011.

BACHELARD, Gaston. A Poética do Espaço. Tradução Antonio de Pádua Danesi. - 2.ed. São Paulo: Martins Fontes, 2008.

BRAIT, Beth. A personagem. 5.ed. São Paulo: Ática, 1993.

CANDIDO, Antonio. A personagem do romance. In: CANDIDO, Antonio; ROSENFELD, Anatol; PRADO; Décio de Almeida; GOMES, Paulo Emílio Salles. A personagem de ficção. 10. ed. São Paulo: Perspectiva, 2002.

CRETTIEZ, Xavier. As formas da violência. Tradução Lara Christina de Malimpensa, Mariana Paolozzi Sérvulo da Cunha. São Paulo: Edições Loyola, 2011.

DE PLÁCIDO E SILVA, Vocabulário Jurídico. Rio de Janeiro: Forense, vol. III e IV, 1996. DIMAS, Antonio. Espaço e romance. São Paulo: Ática, 1987.

FERREIRA, A. B. H. Novo dicionário Aurélio de Língua Portuguesa. Rio de Janeiro: Nova Fronteira, 1986.

FORSTER, E. M. Aspectos do romance. Tradução Sérgio Alcides. São Paulo: Globo, 2014.

JAKOBSON, Roman. Do realismo artístico. In.:Formalistas russos. - 3.ed. Traduzido por Editora Globo. Porto Alegre: Globo, 1976.

LINS, Paulo. Cidade de Deus. São Paulo: Planeta, 2012.

MAIA, Ana Paula. Assim na terra como embaixo da terra. Rio de Janeiro: Record, 2017.

MARGATO, I.; GOMES, R. C. Novos realismos. Belo Horizonte: Editora UFMG, 2012.

MENDES, Fábio Marques. Realismo e violência na literatura contemporânea: os contos de Famílias terrivelmente felizes, de Marçal Aquino. São Paulo: Cultura Acadêmica, 2015.

PELLEGRINI, Tânia. Realismo: postura e método. Letras de hoje. Porto Alegre, v. 42, n. 4, p. 137-155, dezembro 2007.

PELLEGRINI, Tânia. Realismo e realidade na literatura: um modo de ver o Brasil. São Paulo: Alameda, 2008.

PELLEGRINI, Tânia. Realismo: a persistência de um mundo hostil. Revista Brasileira de Literatura Comparada, n.14, 2009.

PELLEGRINI, Tânia. Realismo: Estudos de Literatura Brasileira Contemporânea, n.39, p.11-17, 5 jun. 2012.

ROSENFELD, Anatol. Literatura e Personagem. In.: CANDIDO, Antonio; ROSENFELD, Anatol; PRADO; Décio de Almeida; GOMES, Paulo Emílio Salles. A personagem de ficção. 10. ed. São Paulo: Perspectiva, 2002. 
SCHØLLHAMMER, Karl Erik. Cena do crime: violência e realismo no Brasil contemporâneo. Rio de Janeiro: José Olympio, 2013.

ZIZEK, Slavoj. Violência: seis reflexões laterais. Tradução Miguel Serras Pereira. São Paulo: Boitempo, 2014. 